\title{
NITROGEN AND POTASSIUM IN SAFFLOWER: CHLOROPHYLL INDEX, BIOMETRIC CHARACTERISTICS AND WATER USE EFFICIENCY ${ }^{1}$
}

\author{
ELLEN CRISTINA ALVES DE ANICÉSIO ${ }^{2}$, EDNA MARIA BONFIM-SILVA ${ }^{2 *}$, TONNY JOSÉ ARAÚJO DA SILVA², \\ ADRIANO BICIONI PACHECO ${ }^{2}$
}

\begin{abstract}
Safflower crops is usually intended for production of seeds to oil extraction. The objective of this work was to evaluate the chlorophyll index, biometric characteristics and water use efficiency of safflower plants grown under different nitrogen and potassium rates and controlled soil water tension. The experiment was conducted in a greenhouse, in pots containing $8 \mathrm{dm}^{3}$ of a Oxisol. A complete randomized block experimental design in a $5 \times 5$ factorial arrangement was used, with four replications, consisting of five nitrogen rates $\left(0,60,120,180\right.$ and $\left.240 \mathrm{mg} \mathrm{dm}^{-3}\right)$ and five potassium rates $\left(0,50,100,150\right.$ and $\left.200 \mathrm{mg} \mathrm{dm}^{-3}\right)$. The safflower number of leaves, stem diameter, chlorophyll index, number of capitula, shoot, root and total dry weights, water consumption and water use efficiency were evaluated. Data were subjected to analysis of variance (F test) at $5 \%$ of probability and to polynomial regression. The nitrogen and potassium fertilization, as independent factors, affected the safflower plants. The chlorophyll index, biometric characteristics and water use efficiency of safflower showed better responses under nitrogen rates of 82 to $168 \mathrm{mg} \mathrm{dm}^{-3}$. The responses of chlorophyll index, biometric characteristics and water use efficiency of safflower increased 10 to $60 \%$ with potassium fertilization.
\end{abstract}

Keywords: Carthamus tinctorius L.. Fertilization. Plant production.

\section{NITROGÊNIO E POTÁSSIO EM CÁRTAMO: ÍNDICE DE CLOROFILA, CARACTERÍSTICAS BIOMÉTRICAS E USO DA ÁGUA}

RESUMO - O cártamo destina-se à produção de grãos para a obtenção de óleo vegetal. Objetivou-se avaliar o índice de clorofila, as características biométricas e a eficiência no uso da água de plantas de cártamo sob doses de nitrogênio e potássio. O experimento foi conduzido em casa de vegetação, em vasos contendo $8 \mathrm{dm}^{3} \mathrm{de} \mathrm{um}$ Latossolo Vermelho. O delineamento experimental foi blocos casualizados, com esquema fatorial $5 \times 5$ correspondente a cinco doses de nitrogênio $\left(0,60,120,180\right.$ e $\left.240 \mathrm{mg} \mathrm{dm}^{-3}\right)$ e cinco doses de potássio $(0,50$, 100, 150 e $200 \mathrm{mg} \mathrm{dm}^{-3}$ ), com quatro repetições. Avaliou-se o número de folhas, diâmetro de caule, índice de clorofila, número de capítulos, massa seca da parte aérea, massa seca de raízes, massa seca total, consumo de água e eficiência no uso da água. Os dados foram submetidos a $5 \%$ de probabilidade de erro a análise de variância pelo teste $\mathrm{F}$ e regressão polinomial. O índice de clorofila, as características biométricas e a eficiência no uso da água das plantas de cártamo apresentaram melhores respostas nas doses de nitrogênio entre 82 a 168 $\mathrm{mg} \mathrm{dm}{ }^{-3}$. A adubação potássica nas plantas de cártamo proporcionou respostas crescentes com incrementos de 10 a 60\% para o índice de clorofila, nas características biométricas e na eficiência de uso da água. As respostas a adubação com nitrogênio e potássio no cártamo ocorrem com efeito isolado.

Palavras-chave: Carthamus tinctorius L.. Adubação. Produção vegetal.

\footnotetext{
${ }^{*}$ Corresponding author

${ }^{1}$ Received for publication in 08/14/2016; accepted in 05/03/2017.

Paper extracted from the dissertation masters of the first author.

${ }^{2}$ Institute of Agricultural Sciences and Technology, Universidade Federal de Mato Grosso, Rondonópolis, MT, Brazil; ellencristinaa@hotmail.com, embonfim@hotmail.com, tonnyjasilva@hotmail.com, ad.pacheco@hotmail.com.
} 


\section{INTRODUCTION}

Safflower (Carthamus tinctorius L.) crops is usually intended for production of seeds to oil extraction, which has high quality as human food and potential for biofuel production (DORDAS; SIOULAS, 2008; SHAHROKHNIA; SEPASKHAH, 2016).

Safflower is an herbaceous plant with good adaptability to hot and dry climate conditions due to its deep root system, thus, it is an alternative for crop rotation in Brazil (ANICÉSIO et al., 2015; BONFIM-SILVA et al., 2015).

However, the expansion of safflower crops depends on studies on soil fertilization for recommendation of adequate fertilizer rates for the nutritional balance of this species, increasing its yield, technical efficiency and economic return of the initial investment (WENDLING et al., 2008).

Nitrogen is one of the most required nutrients by plants, since it is part of proteins, enzymes, chlorophyll, nucleic acids, and contribute to hormone synthesis (TAIZ; ZEIGER, 2013).

Potassium is the most concentrated cation in plants, with important physiological and metabolic functions, such as enzymatic activation, photosynthesis and translocation of assimilates, thus, it can be a limiting factor for crop yields (TAIZ; ZEIGER, 2013).

Potassium is the most common nutrient interacting with nitrogen in crops. Growth stimulation by nitrogen fertilization requires adequate potassium fertilization; otherwise, deficiency of this nutrient may occur due to dilution (CANTARELLA, 2007).

Nitrogen excess increases protein content of plants, to the detriment of carbohydrates, resulting in excessive development of the plant shoot in relation to its root system, thus, it may increase lodging (MARSCHNER, 1986). On the other hand, potassium increases resistance to plant lodging, probably by contributing to increase the stem diameter and acceleration of lignification of sclerenchyma cells (PRETTY, 1982).

These nutrients are directly related to the water use efficient of crops. Adequate nitrogen fertilization increases the root system depth, resulting in a higher volume of soil used, reducing the effects of water deficit (DORDAS; SIOULAS, 2008). Potassium maintains the plant maximum photosynthetic capacity with the lowest water loss possible through osmotic control and opening and closing of stomata (FARQUHAR; SHARKEY, 1982).

An appropriate nitrogen and potassium fertilization can also increase the chlorophyll index of leaves, which is related positively to nutritional and production characteristics of plants, increasing photosynthesis and production of assimilates retained by biometric structures (TAIZ; ZEIGER,
2013).

According to Bonfim-Silva et al. (2015), nitrogen fertilization increases chlorophyll index and biometric characteristics of safflower crops. Shahrokhnia and Sepaskhah (2016) found increases in productive components and greater water use efficiency in safflower crops with greater availability of nitrogen.

Abbadi, Gerendas and Sattelmacher (2008), Hussien and Wuhaib (2010) and Palizdar, Delkhosh and Shirani Rad (2011) observed increases in biometric characteristics and higher yields in safflower crops with greater availability of potassium. However, studies evaluating the interaction of nitrogen with potassium on safflower growth are still scarce in the literature.

Thus, the objective of this work was to evaluate the chlorophyll index, biometric characteristics and water use efficiency of safflower plants grown in a Oxisol under different nitrogen and potassium rates and controlled soil water tension.

\section{MATERIAL AND METHODS}

The experiment was conducted in a greenhouse of the Institute of Agricultural Sciences and Technology of the Federal University of Mato Grosso, Rondonópolis, State of Mato Grosso, Brazil (16 $27^{\prime} 49^{\prime \prime} \mathrm{S}, 50^{\circ} 34^{\prime} 47^{\prime \prime} \mathrm{W}$ and altitude of $284 \mathrm{~m}$ ), from July to September, 2014. A complete randomized block experimental design in a $5 \times 5$ factorial arrangement was used, with four replications, consisting of five nitrogen rates $(0,60$, 120,180 and $\left.240 \mathrm{mg} \mathrm{dm}^{-3}\right)$ and five potassium rates $\left(0,50,100,150\right.$ and $\left.200 \mathrm{mg} \mathrm{dm}^{-3}\right)$.

The soil used was a Oxisol (EMBRAPA, 2013), collected from the layer $0.0-0.2 \mathrm{~m}$ of an area with Cerrado vegetation. The soil was sieved in a 2-mm mesh sieve (EMBRAPA, 2011) for chemical and granulometry analysis, which showed $\mathrm{pH}$ $\left(\mathrm{CaCl}_{2}\right)=4.1, \mathrm{P}=2.4 \mathrm{mg} \mathrm{dm}{ }^{-3}, \mathrm{~K}=28 \mathrm{mg} \mathrm{dm}^{-3}$, $\mathrm{Ca}=0.3 \quad \mathrm{cmol}_{\mathrm{c}} \quad \mathrm{dm}^{-3}, \quad \mathrm{Mg}=0.2 \quad \mathrm{cmol}_{\mathrm{c}} \quad \mathrm{dm}^{-3}$, $\mathrm{Al}=1.1 \mathrm{cmol}_{\mathrm{c}} \mathrm{dm}^{-3}, \mathrm{H}=4.2 \mathrm{cmol}_{\mathrm{c}} \mathrm{dm}^{-3}$, organic matter $=22.7 \mathrm{~g} \mathrm{dm}^{-3}$, sum of bases $=0.6 \mathrm{cmol}_{\mathrm{c}} \mathrm{dm}^{-3}$, cation exchange capacity $=5.9 \quad \mathrm{cmol}_{\mathrm{c}} \mathrm{dm}^{-3}$, base saturation $=9.8 \%$, sand $=549 \mathrm{~g} \mathrm{~kg}^{-1}$, silt $=84 \mathrm{~g} \mathrm{~kg}^{-1}$ and clay $=367 \mathrm{~g} \mathrm{~kg}^{-1}$.

The experiment was conducted in pots containing $8 \mathrm{dm}^{3}$ of soil sieved in a $4 \mathrm{~mm}$. Liming was performed after soil homogenization, using dolomitic limestone $(\mathrm{TNP}=80.3)$, to increase the base saturation to $60 \%$. Subsequently, the soil irrigated to $60 \%$ of the water retention capacity, sealed in plastic bags and incubated for 30 days.

Planting fertilization with phosphorus and micronutrients was carried out with the recommended rates, using single superphosphate $\left(150 \mathrm{mg} \mathrm{P}_{2} \mathrm{O}_{5} \mathrm{dm}^{-3}\right), 1 \mathrm{mg} \mathrm{dm}^{-3}$ of $\mathrm{B}$ (boric acid) and $\mathrm{Cu}$ (chloride copper), $3 \mathrm{mg} \mathrm{dm}^{-3}$ of $\mathrm{Mn}$ (manganese 
chloride) and $\mathrm{Zn}$ (zinc sulfate) and $0.2 \mathrm{mg} \mathrm{dm}^{-3}$ of Mo (sodium molybdate).

Potassium fertilization $(0,50,100,150$ and $200 \mathrm{mg} \mathrm{dm}^{-3}$ ) was divided into two applications, at planting and 10 days after emergence (DAE), using pure potassium chloride. Nitrogen fertilization $(0$, $60,120,180$ and $240 \mathrm{mg} \mathrm{dm}^{-3}$ ) was carried out at 10 , 20 and 30 DAE, using urea. Four safflower plants were used per pot, using the cultivar IMA-0213.

Irrigation was carried out by a subsurface self-irrigation system as described by Bonfim-Silva, Monteiro and Silva (2007), consisting of a porous ceramic capsule (height of $9 \mathrm{~cm}$, diameter of $5 \mathrm{~cm}$ and wall thickness of $0.5 \mathrm{~cm}$ ) connected to a reservoir (Mariotte bottle) by a transparent flexible microtube (Figure 1).

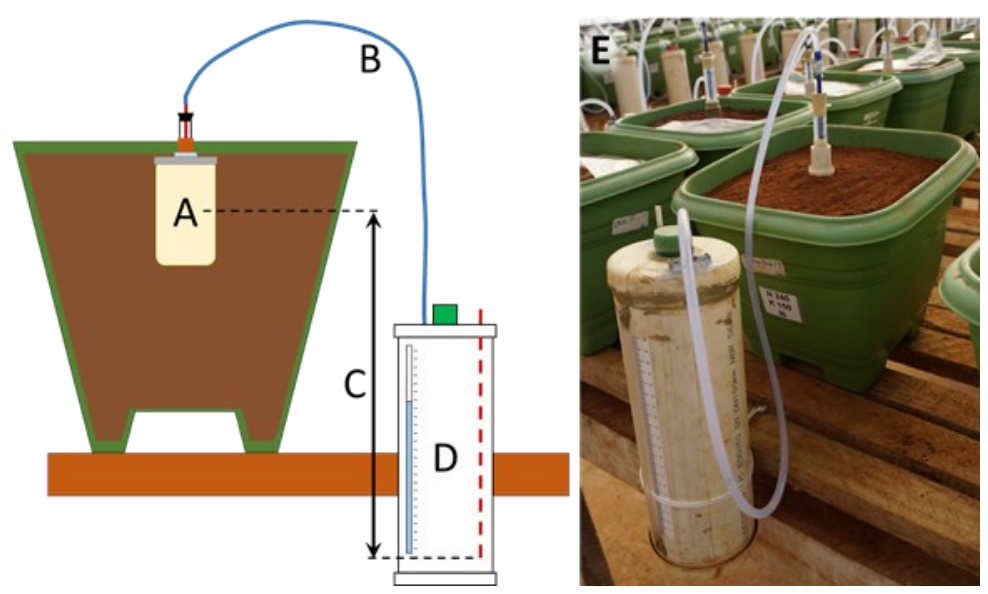

Figure 1. Self-irrigating system. Porous capsule (A), transparent microtube (B), water column height (C), graduated water reservoir (Mariotte bottle) (D) and system implemented (E)

The self-irrigating system continuously supplied the amount of water lost by the evapotranspiration of the soil-plant system. The reservoir was graded with a numerical scale to determine the water consumption of the experimental unit (Figure 1D).

The control of soil water tension was defined by the height of the water column (Figure 1C). Changes in soil water tension during the experiment were carried out according to the crop requirement, maintaining it at 3 (0-20 DAE), 4 (20-45 DAE) and 2 (45-74 DAE) $\mathrm{kPa}$.

Number of leaves, stem diameter and chlorophyll index were evaluated at 55 and 74 DAE. The number of capitula and shoot, root and total dry weight, water consumption and water use efficiency were evaluated at 74 DAE.

The stem diameter was measured at $2 \mathrm{~cm}$ from the soil surface using an analog caliper. Chlorophyll index were assessed using a Minolta SPAD-502 chlorophyll meter in five random leaves of the middle third of the plants.

The plants were removed from the soil and their shoots were separated to evaluate the number of capitula and shoot dry weight (sum of the leaves, stems and capitula dry weights). The roots were washed under a $4 \mathrm{~mm}$ sieve. The root and shoot dry weights were measured in a semi-analytical balance after the plant parts were dried in a forced-air circulation oven at $65^{\circ} \mathrm{C}$ for 72 hours.

The scale of the reservoir level $(\mathrm{cm})$ was based on the reservoir diameter, converted into volume $\left(\mathrm{dm}^{3}\right)$. This scale was used to quantify the water consumption, considering the water content of the reservoir before and after its replenishing. The amount of water consumed from planting to $74 \mathrm{DAE}$ were summed to obtain the total water consumption.

The water use efficiency $\left(\mathrm{g} \mathrm{dm}^{-3}\right)$ of the plants as a function of nitrogen and potassium rates (Equation 1) was calculated from the relation between the plant total dry weight $\left(\mathrm{g} \mathrm{pot}^{-1}\right)$ and total water consumption $\left(\mathrm{dm}^{3} \operatorname{pot}^{-1}\right)$.

$$
\text { Water use efficiency }=\frac{\text { Total dry weight }}{\text { Water consumption }}(\text { Equation 1) }
$$

The variables were subjected to a response surface study, using the Statistical Analysis System (SAS INSTITUTE, 2002). The combinations of nitrogen and potassium rates were subjected to analysis of variance and significant means by the $\mathrm{F}$ test were subjected to the response surface study, using the RSREG command. Non-significant results of the interaction between nitrogen and potassium rates were subjected to the study of independent factors by polynomial regression, using the GLM command. The analyses were performed with significance level of $5 \%$.

\section{RESULTS AND DISCUSSION}


The chlorophyll index of the treatments were significantly affected only by the nitrogen rates, described by a quadratic model, showing the highest index (60.5) with the nitrogen rate of $168 \mathrm{mg} \mathrm{dm}^{-3}$ at
55 DAE. The chlorophyll index increased due to the nitrogen rates at $74 \mathrm{DAE}$, described by a linear equation (Figure 2).

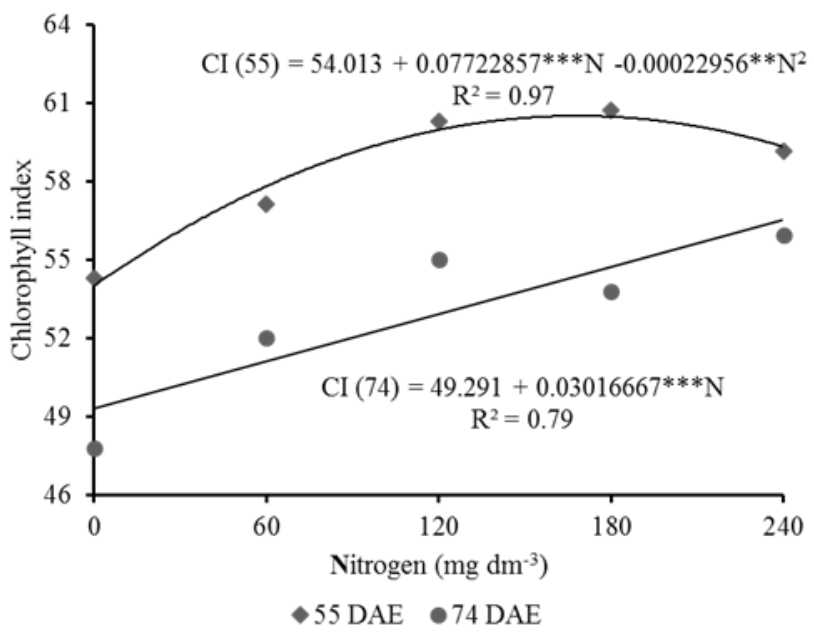

Figure 2. Chlorophyll index (CI) of safflower plants grown in a Oxisol, at 55 and 74 days after emergence (DAE), as a function of nitrogen rates. $* * *=$ significant at $0.1 \%$ and $* *=$ significant at $1 \%$.

Nitrogen is part of the chlorophyll molecule, thus, its adequate rate increases plant photosynthesis and growth (TAIZ; ZEIGER, 2013). Dordas and Sioulas (2008) found higher rates of photosynthesis with increasing chlorophyll index in safflower plants. Thus, within certain limits, the chlorophyll index of the leaves is positively related to the plant production, due to the accumulation of photoassimilates. The decreasing chlorophyll index over time found in the present work was probably due to the process of nitrogen redistribution in the plant, since the plant flowering occurred in the second evaluation, and part of the nitrogen was translocated to the capitula through the source-drain relation.

The nitrogen and potassium rates, as independent factors, affected the number of leaves. The data of the treatments with nitrogen rates were fitted to a quadratic equation, showing the highest number of leaves with the rates of 123 (55 DAE) and 128 (74 DAE) $\mathrm{mg} \mathrm{dm}^{-3}$ (Figure 3A).
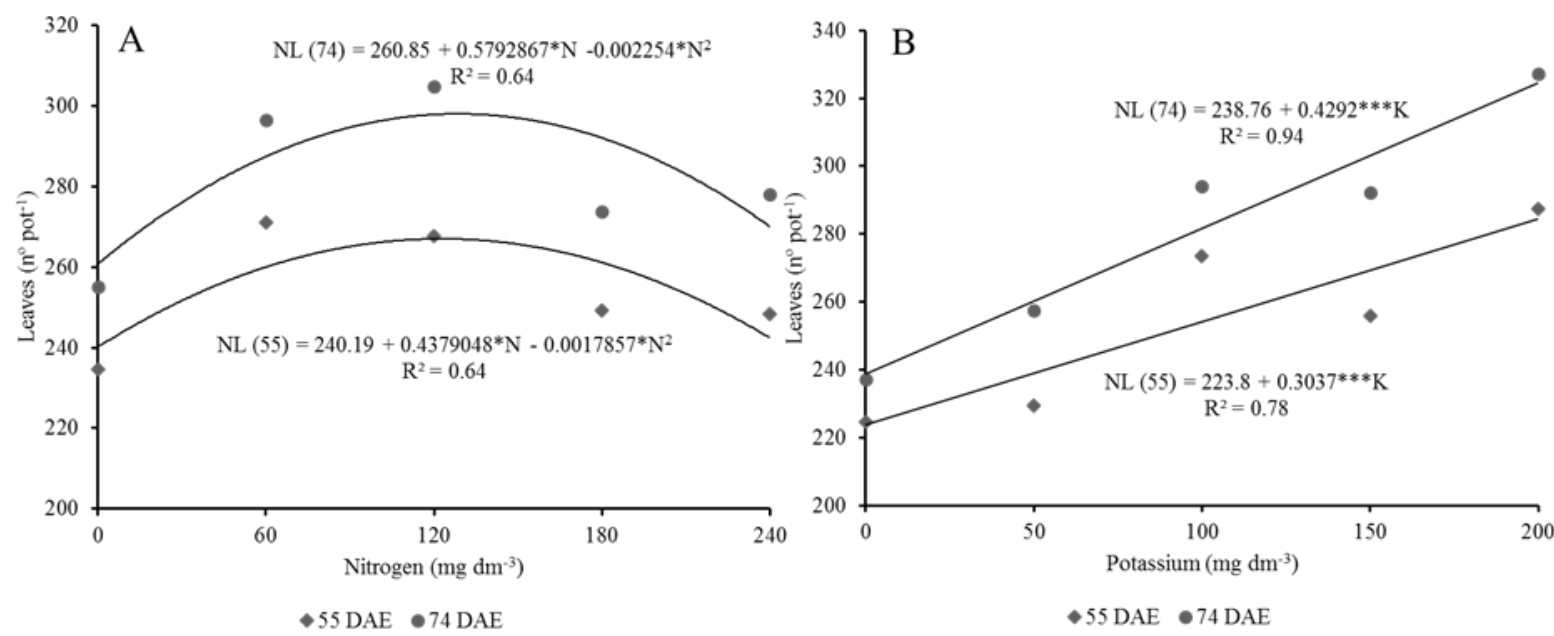

Figure 3. Number of leaves (NL) of safflower plants grown in a Oxisol, at 55 and 74 days after emergence (DAE), as a function of nitrogen $(\mathrm{A})$ and potassium $(\mathrm{B})$ rates, $* * *=$ significant at $0.1 \%$ and $*=$ significant at $5 \%$.

These results were similar to those found by Bonfim-Silva et al. (2015), who found increases in number of leaves of safflower due to nitrogen fertilization, reporting the highest number of leaves with rates of 118 (25 DAE), 132 (45 DAE) and 162
(65 DAE) $\mathrm{mg} \mathrm{dm}^{-3}$. Increases in number of leaves due to nitrogen fertilization usually increase leaf area, thus promoting a greater area of incidence of solar radiation, carbon assimilation and plant growth and production (CRUZ et al., 2007). 
The number of leaves of treatments with potassium rates were fitted to a linear equation, the treatment with the highest rate $\left(200 \mathrm{mg} \mathrm{dm}^{-3}\right)$ showing an increase of 21 (55 DAE) and 26\% (74 DAE) compared with the treatment without potassium fertilization (Figure 3B). Potassium fertilization increases the number of leaves due to its contribution to several biochemical processes, such as carbohydrate metabolism, photosynthesis, respiration and enzymatic activation (COELHO et al., 2007).

The nitrogen and potassium rates, as independent factors, significantly affected the stem diameter in both evaluations (Figure 4). The stem diameter data of the treatments with nitrogen fertilization were fitted to a quadratic equation, with the highest SD found with nitrogen rates of $106 \mathrm{mg} \mathrm{dm}^{-3}$, at $55 \mathrm{DAE}(6.6 \mathrm{~mm})$ and $87 \mathrm{mg} \mathrm{dm}^{-3}$, at $74 \mathrm{DAE}(6.21 \mathrm{~mm})$ (Figure $4 \mathrm{~A})$.
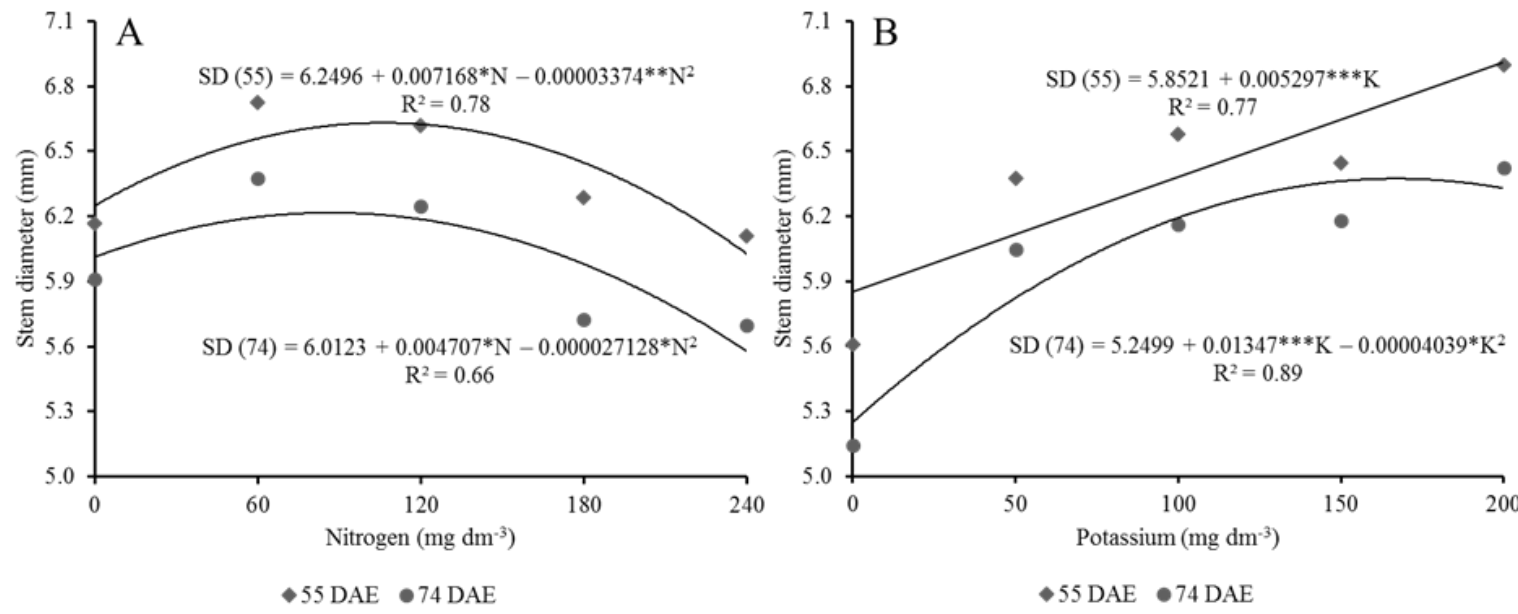

Figure 4. Stem diameter (SD) of safflower plants grown in a Oxisol, at 55 and 74 days after emergence (DAE), as a function of nitrogen $(\mathrm{A})$ and potassium $(\mathrm{B})$ rates. $* * *=$ significant at $0.1 \%, * *=$ significant at $1 \%$ and $*=$ significant at $5 \%$.

The stem diameter was lower in the second evaluation (Figure 4A) because the plants were at the end of the flowering stage, beginning the process of translocation of carbohydrate reserves from the stem to the capitula. According to Dordas and Sioulas (2009), stem reserves can be used for grain filling.

The stem diameter data of the treatments with potassium rates were fitted to a linear equation at $55 \mathrm{DAE}$, and to a quadratic equation at $74 \mathrm{DAE}$, with maximum stem diameter of $6.37 \mathrm{~mm}(167 \mathrm{mg}$ $\mathrm{dm}^{-3}$ ), showing an increase of $17.6 \%$, compared with the treatment without potassium fertilization (Figure 4B). These results show the importance of nutritional balance for these plants, since excess nitrogen

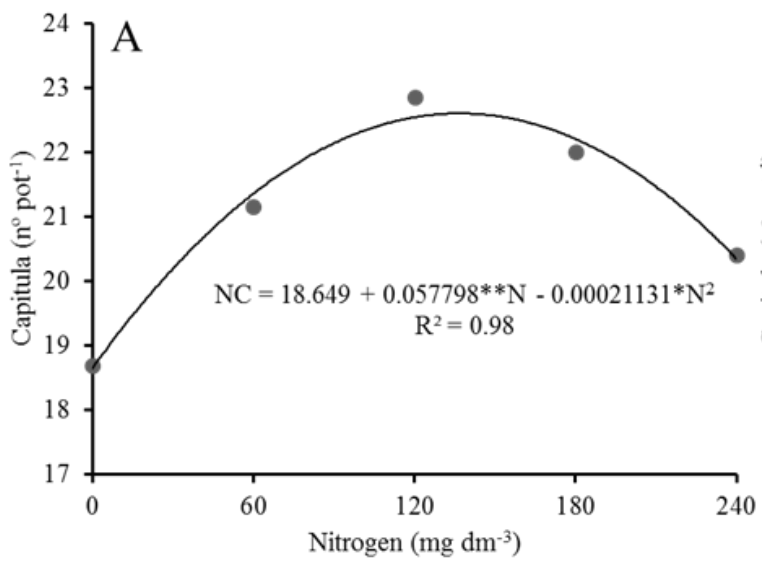

reduced the stem diameter and the potassium fertilization favored this variable, even at higher rates. The stem diameter of safflower is important for crop management, since a high stem diameter reduce plant lodging, facilitating cultural practices and harvesting (BISCARO et al., 2008).

The nitrogen and potassium rates, as independent factors, affected the number of capitula, whose data showed a linear response to nitrogen and a quadratic response to potassium fertilization (Figure 5). The highest number of capitula (22) was found under nitrogen fertilization of $137 \mathrm{mg} \mathrm{dm}^{-3}$ (Figure 5A).

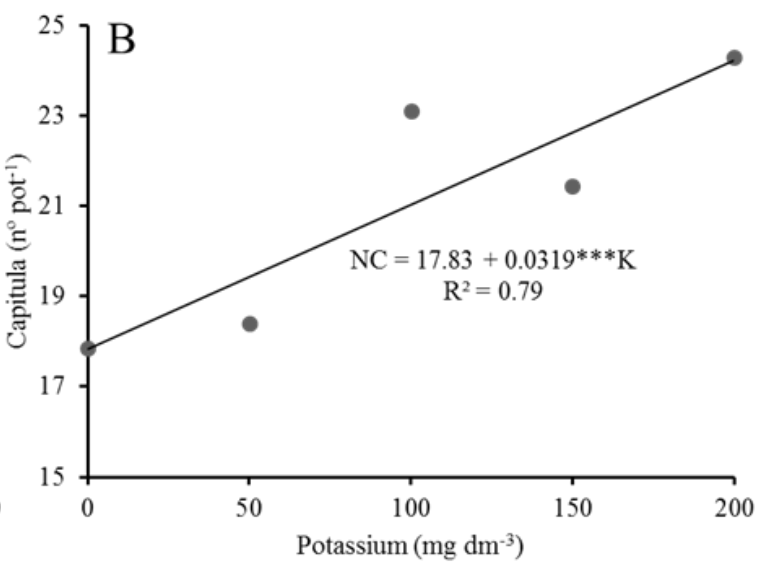

Figure 5. Number of capitula (NC) of safflower plants grown in a Oxisol, at 74 days after emergence (DAE), as a function of nitrogen (A) and potassium (B) rates. $* * *=$ significant at $0.1 \%$, $* *=$ significant at $1 \%$ and $*=$ significant at $5 \%$.

Rev. Caatinga, Mossoró, v. 31, n. 2, p. 424 - 433, abr. - jun., 2018 
Number of capitula per plant is an important yield component due to its direct relation with the final crop yield. Nitrogen increases vegetative growth, leading to a better fruiting. The results of the present work confirm those found by Gilbert and Tucker (1967) and Jones and Tucker (1968), who reported increases in yield components of safflower, especially number of capitula and seed weight per plant, as a function of nitrogen fertilization.

The higher potassium rate used $\left(200 \mathrm{mg} \mathrm{dm}^{-3}\right)$ increased the number of capitula in $26.35 \%$, compared with the treatment without potassium fertilization (Figure 5B). This result is similar to those reported by Palizdar, Delkhosh and Shirani

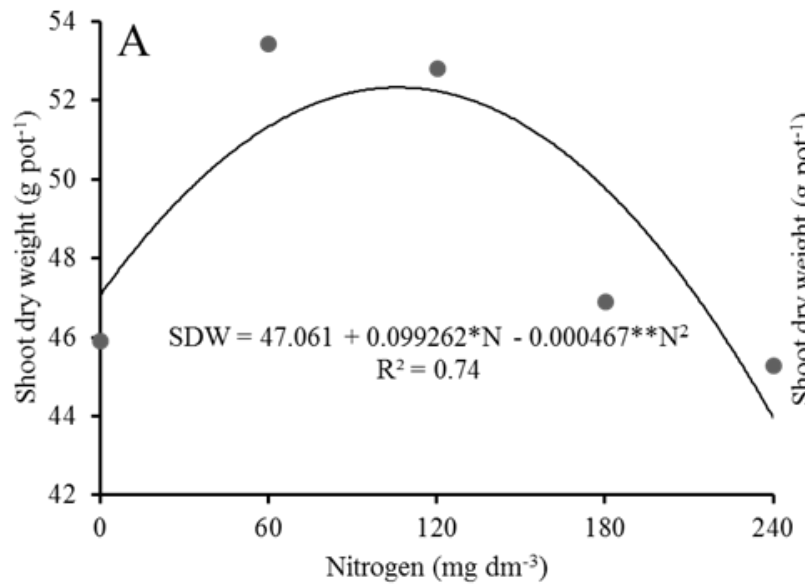

Rad (2011), who found greater number of capitula with potassium rate of $150 \mathrm{~kg} \mathrm{ha}^{-1}$ in a safflower crop, with an increase of $40 \%$, compared with plants without potassium fertilization.

The nitrogen and potassium rates, as independent factors, significantly affected the shoot dry weight (Figure 6), whose data were fitted to a quadratic equation, with the highest yield (52.33 $\mathrm{g} \mathrm{pot}^{-1}$ ) found with the nitrogen rate of $106 \mathrm{mg} \mathrm{dm}^{-3}$ (Figure 6A). This result was similar to that found by Bonfim-Silva et al. (2015), who found increases in shoot dry weight with nitrogen rates of up to $177.02 \mathrm{mg} \mathrm{dm}^{-3}$.

Figure 6. Shoot dry weight (SDW) of safflower plants grown in a Oxisol, at 74 days after emergence (DAE), as a function of nitrogen (A) and potassium (B) rates. $* * *=$ significant at $0.1 \%, * *=$ significant at $1 \%$ and $*=$ significant at $5 \%$.

The shoot dry weight data had a linear response to the potassium rates, with an increase of $35 \%$, comparing the treatment with the highest rate $\left(200 \mathrm{mg} \mathrm{dm}^{-3}\right)$ with the treatment without potassium fertilization (Figure 6B).

The potassium rates, as an independent factor, significantly affected the root dry weight, whose data were fitted to a linear equation, with an increase of $33 \%$, comparing the treatment with the higher potassium rate with the treatment without potassium fertilization (Figure 7).

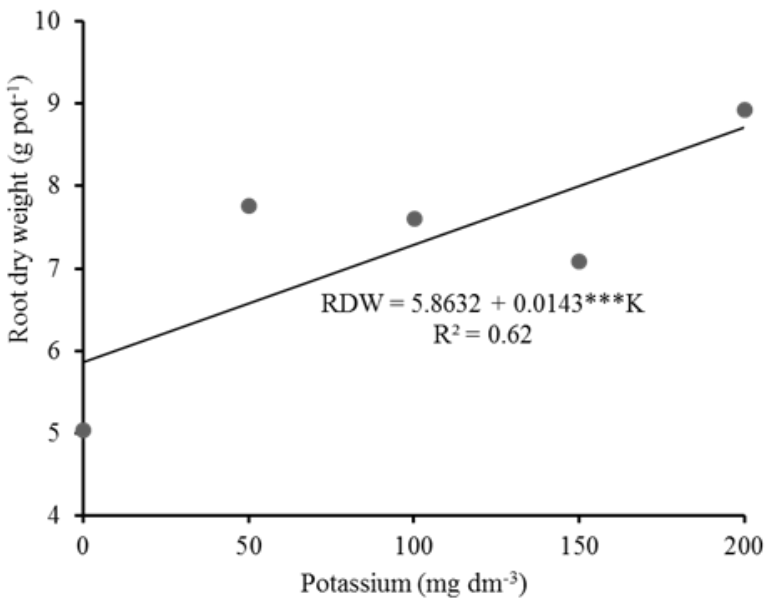

Figure 7. Root dry weight (RDW) of safflower plants grown in a Oxisol, at 74 days after emergence (DAE), as a function of potassium rates. $* * *=$ significant at $0.1 \%$. 
The root dry weight was lower in treatments without potassium fertilization, denoting the effect of the nutritional status of the plants, especially regarding potassium, on root growth (ESHEL; WAISEL, 1996). Potassium contributes to transport of nitrate to the plant shoot and photoassimilates by the phloem, enzymatic activation and osmotic regulation, favoring the root growth (MALAVOLTA; VITTI; OLIVEIRA, 1997) and consequently, the shoot growth.

Hussien and Wuhaib (2010) found similar results evaluating safflower growth under potassium rates $\left(0,45,90,135\right.$ and $180 \mathrm{~kg} \mathrm{ha}^{-1}$ of $\left.\mathrm{K}_{2} \mathrm{SO}_{4}\right)$, with higher root dry weight with $180 \mathrm{~kg} \mathrm{ha}^{-1}$.

The nitrogen and potassium rates, as independent factors, significantly affected the total dry weight, whose data were fitted to quadratic (nitrogen) and linear (potassium) equations (Figures $8 \mathrm{~A}$ and $\mathrm{B})$. The maximum total dry weight $\left(60 \mathrm{~g} \mathrm{pot}^{-1}\right)$ was found with the nitrogen rate of $102 \mathrm{mg} \mathrm{dm}^{-3}$.
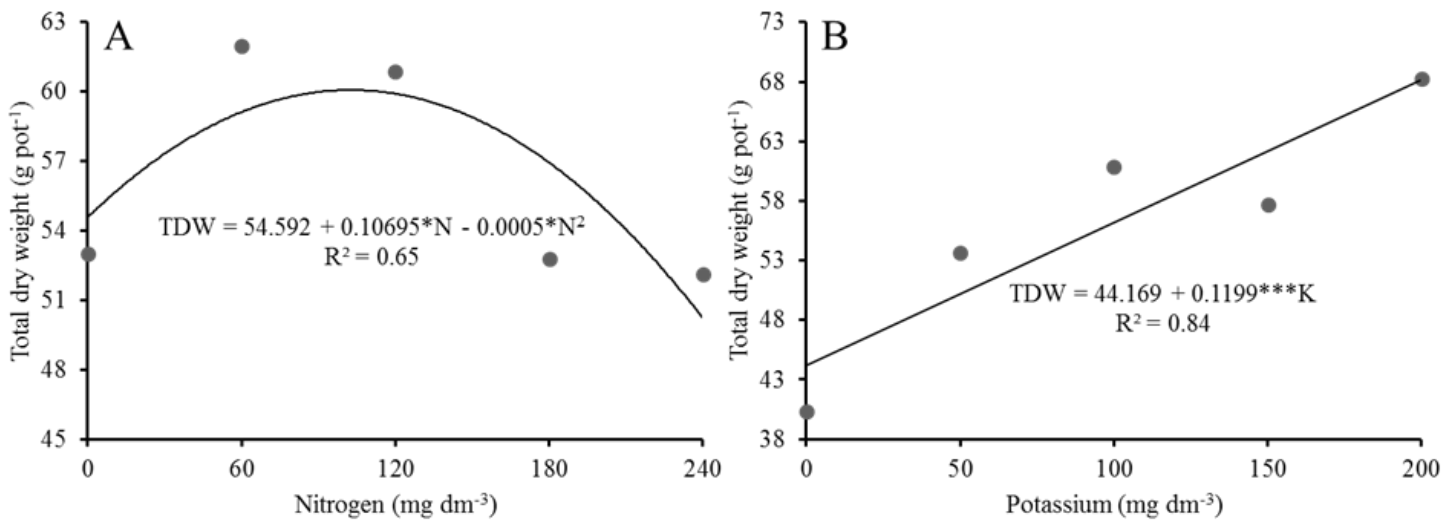

Figure 8. Total dry weight (TDW) of safflower plants grown in a Oxisol, at 74 days after emergence (DAE), as a function of nitrogen (A) and potassium (B) rates. $* * *=$ significant at $0.1 \%, * *=$ significant at $1 \%$ and $*=$ significant at $5 \%$.

Aiyelaagbe, Fagbayide and Makinde (2005), Dordas and Sioulas (2009) and Ebrahimian and Soleymani (2013) found similar results, with significant response of total dry weight of safflower plants to nitrogen fertilization.

Nitrogen fertilization affected positively the total dry weight of safflower plants, since this nutrient is part of all amino acids, amides, proteins, nucleic acids, nucleotides, polyamines, plant hormones and several other types of metabolic components (EPSTEIN; BLOOM, 2006).

The highest total dry weight under potassium fertilization was found with the rate of $200 \mathrm{mg} \mathrm{dm}^{-3}$, with an increase of $35 \%$, compared with the treatment without potassium fertilization (Figure
8B), showing the positive effect of potassium fertilization on the total dry weight of safflower plants. Similar results were found by Abbadi, Gerendas and Sattelmacher (2008), evaluating safflower plants in greenhouse conditions (28 and $15{ }^{\circ} \mathrm{C}$ ) on substrates with different potassium rates, with maximum total dry weight under the potassium rate of $90 \mathrm{mg} \mathrm{dm}^{-3}$.

The potassium rates, as an independent factor, significantly affected the water consumption. The water consumption data were fitted to a linear equation, showing an increase of $10 \%$, compared with the treatment without potassium fertilization (Figure 9).

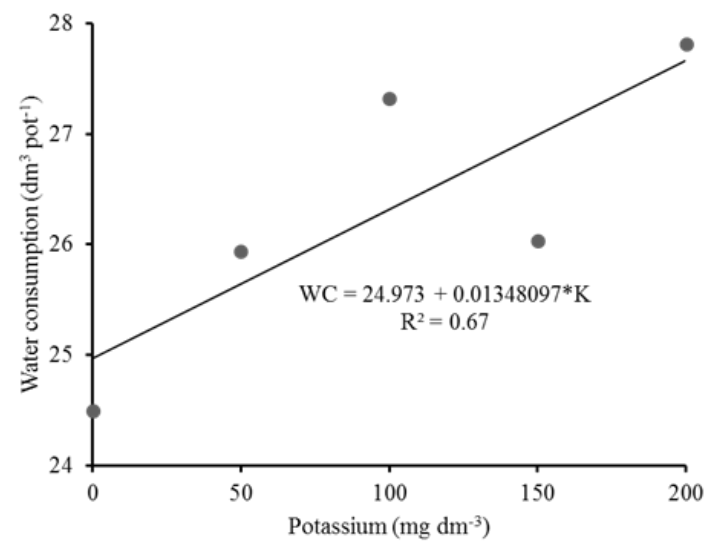

Figure 9. Water consumption (WC) of safflower plants grown in a Oxisol, at 74 days after emergence (DAE), as a function of potassium rates. $*=$ significant at $5 \%$. 
According to Reichardt (1978), the evapotranspiration of plants with good establishment and development is mainly affected by the transpiration rate, which becomes higher than the evaporation rate. Therefore, plants with higher dry weight present higher water consumption.

The nitrogen and potassium rates, as

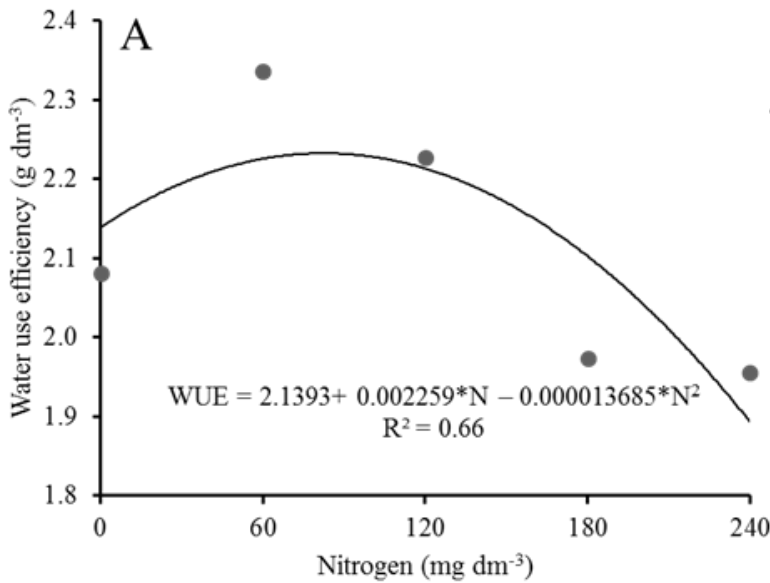

Figure 10. Water use efficiency (WUE) of safflower plants grown in a Oxisol, at 74 days after emergence (DAE), as a function of nitrogen (A) and potassium (B) rates. ${ }^{* * *}=$ significant at $0.1 \%$ and $*=$ significant at $5 \%$.

Adequate rates of nitrogen increase the plant's ability of use the water intake for dry weight production. Dordas and Sioula (2008) reported an increase of $60 \%$ in water use efficiency by safflower plants due to nitrogen $\left(200 \mathrm{~kg} \mathrm{ha}^{-1}\right)$, compared with plants without nitrogen fertilization. Shahrokhnia and Sepaskhah (2016) also found higher water use efficiency in safflower crops with the nitrogen rate of $200 \mathrm{~kg} \mathrm{ha}^{-1}$. These authors emphasized the importance of this variable in regions of low water availability.

The water use efficiency showed an increasing linear response to potassium rates, with maximum water use efficiency $\left(2.47 \mathrm{~g} \mathrm{dm}^{-3}\right)$ with $200 \mathrm{mg} \mathrm{dm}^{-3}$ (Figure 10B). According to these results, the increasing potassium rates increased the WUE of safflower plants, which better use of the available water in the soil for dry weight production.

Water use efficiency is related to control of stomatal opening and closure, which is dependent on potassium, maintaining a minimum water loss during the absorption of $\mathrm{CO}_{2}$ for photosynthesis (PIMENTEL, 2004), resulting in reduced transpiration rates and larger leaf area per dry weight of the plant (IGBAL et al., 2011).

\section{CONCLUSION}

The nitrogen and potassium fertilization, as independent factors, affected the safflower plants.

The chlorophyll index, biometric characteristics and water use efficiency of safflower

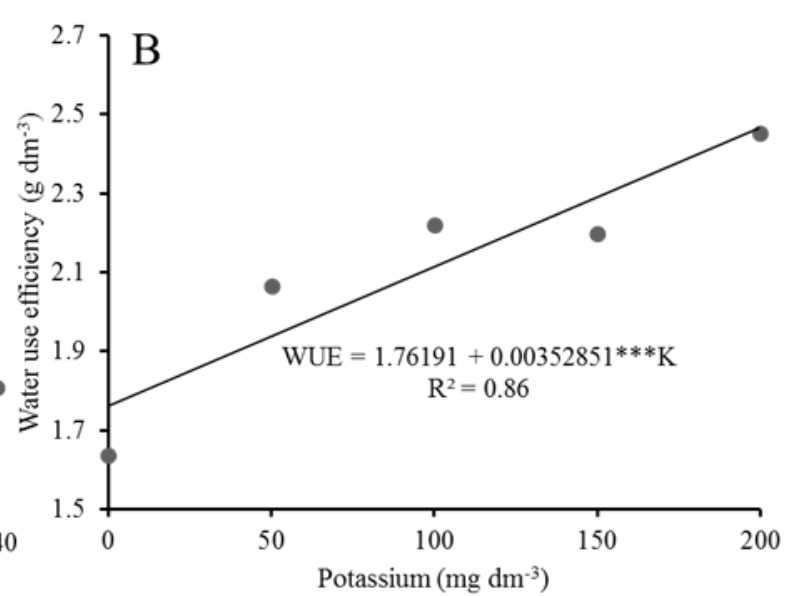

independent factors, affected the water use efficiency, whose data were fitted to quadratic (nitrogen) and linear (potassium) equations (Figure 10). The maximum water use efficiency $\left(2.23 \mathrm{~g} \mathrm{dm}^{-3}\right)$ was found with nitrogen fertilization of $82 \mathrm{mg} \mathrm{dm}^{-3}$ (Figure 10A). plants showed better responses with nitrogen rates of 82 to $168 \mathrm{mg} \mathrm{dm}^{-3}$.

The responses of chlorophyll index, biometric characteristics and water use efficiency of safflower increased 10 to $60 \%$ with potassium fertilization.

\section{ACKNOWLEDGEMENTS}

We thank the CAPES, CNPq e IMAmt (Instituto Mato-grossense do Algodão).

\section{REFERENCES}

ABBADI, J.; GERENDAS, J.; SATTELMACHER, B. Effects of potassium supply on growth and yield of safflower as compared to sunflower. Journal of Plant Nutrition and Soil Science, Tharandt, v. 171, n. 2, p. 272-280, 2008.

AIYELAAGBE, I. O. O.; FAGBAYIDE J. A.; MAKINDE, A. I. Effects of $\mathrm{N}$ fertilization on the vegetative growth of passion fruit (Passiflora edulis f. flavicarpa) seedlings. Journal of Food, Agriculture and Environment, Helsink, v. 3, n. 34, p. 62-64, 2005.

ANICÉSIO, E. C. A. et al. Dry mass, nutrient concentration and accumulation in safflower (Carthamus tinctorius L.) influenced by nitrogen and potassium fertilizations. Australian Journal of Crop Science, Lismore, v. 9, n. 6, p. 552-560, 2015. 
BISCARO, G. A. et al. Adubação nitrogenada em cobertura no girassol irrigado nas condições de Cassilândia-MS. Ciência e Agrotecnologia, Lavras, v. 32, n. 5, p. 1366-1373, 2008.

BONFIM-SILVA, E. M.; MONTEIRO, F. A.; SILVA, T. J. A. Nitrogênio e enxofre na produção e no uso de água pelo capim braquiária em degradação. Revista Brasileira de Ciência do Solo, Viçosa, v. 31, n. 2, p. 309-317, 2007.

BONFIM-SILVA, E. M. et al. Development of Safflower Subjected to Nitrogen Rates in Cerrado Soil. American Journal of Plant Sciences, Starkville, v. 6, n. 13, p. 2136- 2143, 2015.

CANTARELLA, H. Nitrogênio. In: NOVAIS, R. F. et al. (Eds.). Fertilidade do solo. Viçosa: Sociedade Brasileira de Ciência do Solo, 2007. v. 1, cap. 7, p. 375-470.

COELHO, R. I. et al. Resposta à adubação com uréia, cloreto de potássio e ácido bórico em mudas do abacaxizeiro 'Smooth Cayenne'. Revista Brasileira de Fruticultura, Jaboticabal, v. 29, n. 1, p. 161-165, 2007.

CRUZ, J. L. et al. Níveis de nitrogênio e a taxa fotossintética do mamoeiro "Golden". Ciência Rural, Santa Maria, v. 37, n. 1, p. 64-71, 2007.

DORDAS, C. A.; SIOULAS, C. Safflower yield, chlorophyll content, photosynthesis, and water use efficiency response to nitrogen fertilization under rainfed conditions. Industrial Crops and Products, Phoenix, v. 27, n. 1, p. 75-85, 2008.

DORDAS, C. A.; SIOULAS C. Dry matter and nitrogen accumulation, partitioning, and retranslocation in safflower (Carthamus tinctorius L.) as affected by nitrogen fertilization. Field Crops Research, Amsterdam, v. 110, n. 1, p. 35-43, 2009.

EBRAHIMIAN, A.; SOLEYMANI, A. Growth length and dry matter yield in different stages of safflower as affected by nitrogen, phosphorus and potassium fertilizers. International Journal of Agronomy and Plant Production, London, v. 4, n. 5, p. 963-969, 2013.

EMPRESA BRASILEIRA DE PESQUISA AGROPECUÁRIA - EMBRAPA. Manual de métodos de análises de solo. 2. ed. rev. Rio de Janeiro, RJ: Embrapa Solos, 2011. 230 p.

EMPRESA BRASILEIRA DE PESQUISA AGROPECUÁRIA - EMBRAPA. Sistema brasileiro de classificação de solos. 3 . ed. ver. ampl. Brasília, DF: Embrapa, 2013. 353 p.
EPSTEIN, E.; BLOOM, A. J. Nutrição mineral de plantas: princípios e perspectivas. 2. ed. Londrina, PR: Ed. Plantas, 2006. 403 p.

ESHEL, A.; WAISEL, Y. Multiform and multifunction of various constituents of one root system. In: WAISEL, Y.; ESHEL, A.; KAFKAFI, U. (Eds.) Plant roots: The hidden half. 2. ed. New York, Marcel Dekker, 1996. p. 175-19.

FARQUHAR, G. D.; SHARKEY, T. D. Stomatal conductance and photosynthesis. Annual Review of Plant Physiology, Palo Alto, v. 33, n. 1, p. 317-345, 1982.

GILBERT, N. W.; TUCKER, T. C. Growth, yield, and yield components of safflower as affected by source, rate and time of application of nitrogen. Agronomy Journal, Madison, v. 59, n. 1, p. 54-55, 1967.

HUSSIEN, L. A.; WUHAIB, K. M. The relationship between root growth and yield in safflower influenced by irrigation interval and potassium levels. The Iraqi Journal of Agricultural Sciences, Baghdad, v. 41, n. 3, p. 30-45, 2010.

IGBAL, N. et al. Exogenously-sourced ethylene increases stomatal conductance, photosynthesis, and growth under optimal and deficient nitrogen fertilization in mustard. Journal of Experimental Botany, Lancaster, v. 62, n. 14, p. 4955-4963, 2011.

JONES, J. P.; TUCKER, T. C. Effect of nitrogen fertilizer on yield nitrogen content and yield components of safflower. Agronomy Journal, Madison, v. 60, n. 4, p. 363-364, 1968.

MALAVOLTA, E.; VITTI, G. C.; OLIVEIRA, S. A. O. Avaliação do estado nutricional das plantas: princípios e aplicações. 2. ed. Piracicaba, SP: Potafós, 1997. 201 p.

MARSCHNER, H. Mineral nutrition of higher plants. London: Academic Press, 1986. 647 p.

PALIZDAR, M.; DELKHOSH, B.; SHIRANI RAD, A. H. Effect of irrigation regimes on agronomic traits of safflower (Carthamus tinctorius L.) under different levels of $\mathrm{K}$ fertilization. Plant Ecophysiology, Jiroft Branch, v. 3. n. 1, p. 15-21, 2011.

PIMENTEL, C. A relação da planta com a água Seropédica, RJ: EDUR, 2004. 192 p.

PRETTY, K. M. O potássio e a qualidade da produção agrícola. In: YAMADA, T. et al. (Eds.). Potássio na agricultura brasileira. Piracicaba: POTAFOS, 1982. v. 1, cap. 11, p. 177-194. 
REICHARDT, K. A água na produção agrícola. São Paulo, SP: McGraw-Hill do Brasil, 1978. 119 p.

SAS INSTITUTE. SAS: user's guide statistics. 9th Ed. Cary, 2002, 943 p.

SHAHROKHNIA, M. H.; SEPASKHAH, A. R. Effects of irrigation strategies, planting methods and nitrogen fertilization on yield, water and nitrogen efficiencies of safflower. Agricultural Water Management, Amsterdam, v. 172, p. 18-30, 2016.

TAIZ, L.; ZEIGER, E. Fisiologia vegetal. 5. ed. Porto Alegre, RS: Artmed, 2013. 918 p.

WENDLING, A. et al. Recomendação de adubação potássica para o trigo, milho e soja sob sistema de plantio direto no Paraguai. Revista Brasileira de Ciência do Solo, Viçosa, v. 32, n. 5, p. 1929-1939, 2008. 